\title{
Relationship between Ruminal Endotoxin Level and Number of Bacteria in Goats Engorged High-Concentrate Ration
}

\author{
Kyuya SUDA, Miyako YOSHIOKA ${ }^{1)}$, Yoshiko MOTOI ${ }^{1)}$, \\ Yasuo KOBAYASHI ${ }^{2)}$, Masaaki WAKITA ${ }^{2)}$ \\ and Sadao HOSHINO ${ }^{2}$ \\ Kaken Pharmaceutical Co., Ltd., Chuo-ku, Tokyo 103 \\ "National Institute of Animal Ilealth, Tsukuba-shi 305 \\ ${ }^{27}$ Faculty of Bioresources. Mie University. Tsu-shi 514
}

(Received January 6, 1997)

\begin{abstract}
The present study aimed to investigate the relationship between ruminal endotoxin (ET) level and number of bacteria in goats engorged a high-concentrate ration. Three hay-fed goats fitted with ruminal fistula were voluntarily fed with a $90 \%$ concentrate ration in order to induce acidosis. Clinical signs such as anorexia or depression and significant decline of ruminal $\mathrm{pH}$ accompanied with an elevation of VFA level were observed in all goats soon after the change of diet. Molar percentages of acetate and iso-valerianate decreased and that of propionate increased from 6 to $48 \mathrm{~h}$. There were no changes in ruminal $\mathrm{L}(+)-$ and $\mathrm{D}(-)$-lactate levels. Ruminal ET level, however, gradually elevated from $6 \mathrm{~h}$ and, after reaching a maximum level of $167.7 \mathrm{ng} / \mathrm{ml}$ at $24 \mathrm{~h}$, declined to the initial level at $168 \mathrm{~h}$. Both numbers of gram-positive and negative bacteria tended to slightly increase at $24 \mathrm{~h}$. The proportion of gram-positive cocci tended to increase, and that of gram-negative cocci significantly decreased at 6 and $12 \mathrm{~h}$. The significant decrease in total number of protozoa was observed from 6 to $24 \mathrm{~h}$ and $72 \mathrm{~h}$. It was clarified that ruminal ET production increased without a decrease in number of gram-negative bacteria, when ruminal fermentation was activated.
\end{abstract}

Anim. Sci. Technol. (Jpn.) 68 (9): 815-819, 1997

Key words : Acidosis, Bacteria, Endotoxin, Goat, Rumen

Beef cattle is usally given an easily fermentable grain feed in order to promote the growth and to improve the feed efficiency. An accumulation of lactate in rumen, however, often occurred by the ingestion of an excess amount of feed and resulted in acute ruminal acidosis. A high-toxic substance was detected in the ruminal fluids of acidosis cattle $\mathrm{e}^{2)}$ and was thought to be endotoxin (ET) released from dead gram-negative bacterial bodies ${ }^{6)}$. It was also reported that an increase of ruminal ET level was observed after a decrease in the number of gram-negative bacteria in steers ${ }^{9)}$ and goats ${ }^{10)}$, but this matter still remains unclear. Furthermore, Andersen et al. ${ }^{1)}$ assessed the infuence of concentrate diets on ruminal ET level and $\mathrm{pH}$, but the information was not enough. The present study aimed to investigate the relationship between ruminal ET level and number of bacteria in goats engorged a high-concentrate diet.

\section{Materials and Methods}

Three female Tokara goats (body weight 20$35 \mathrm{~kg}$ ) fitted with ruminal fistula were given 400 $\mathrm{g}$ of an alfalfa haycube (TDN $60.2 \%$ ) twice a 
day $(8: 00$ and $17: 00)$ for more than two weeks before the beginning of the experiment. The diet was changed to a $90 \%$ concentrate (TDN) $71.0 \%$, Tokai Kumiai Feed Mill Co.Ltd.) and $10 \%$ alfalfa haycube ration from $8: 00$ on a test day $(0 \mathrm{~h})$ and it was given ad libitum throughout the experiment. The goats had free access to fresh water and a mineral salt block (Kouen, Nippon Zenyaku Kogyo). Ruminal fluids through the fistula from all goats were collected at $-24,0,6,12,24,48,72$ and $168 \mathrm{~h}$ after the change of diet.

The ruminal fluids were filtered through two layers of gauze and, after measuring the $\mathrm{pH}$ (HM-5ES, TOA), a part of the filtrate was mixed at the equivalent rate in $20 \%$ formalin solution for bacterial analysis and in 10\% methylgreen-formalin solution for protozoal analysis. The remaining filtrates were centrifuged at $30,000 \times \mathrm{g}$ for $20 \mathrm{~min}$ and the supernatant fluids were obtained. The fluids were stored in a freezer at $-20^{\circ} \mathrm{C}$ for the later assays of VFA by gas-chromatography (GC-6A, Shimadzu), $L(+)$ - and $D(-)$-lactate by the enzymatic method ${ }^{93}$ (826-UV, Sigma) and ET by the method of turbidimetric-kinetic assay ${ }^{5)}$ (Limulus ES-II, Wako). Numbers of bacteria identified on a stained smear according to Minato's method ${ }^{9>}$ and those of protozoa morphologically identified according to Ogimoto and Imai's method ${ }^{8\rangle}$ were enumerated.

Analysis of Variance in each obtained data was used for statistical analysis and t-test was carried out where the difference was significant.

\section{Results}

All goats consumed about $80 \%$ of the total amount of the high-concentrate ration on the first day of the experiment. The goats showed clinical signs of acidosis such as anorexia or depression soon after the change of diet, and almost recovered from such damages at $168 \mathrm{~h}$. As shown in Table 1, ruminal $\mathrm{pH}$ was significantly depressed at $6 \mathrm{~h}$ in comparison with the initial value $(0 \mathrm{~h}, \mathrm{P}<0.01)$ and the depression continued throughout the experiment. A significant increase in total VFA level was observed from 6 to $168 \mathrm{~h}$ except $72 \mathrm{~h}$ to compare with $0 \mathrm{~h}(6-48 \mathrm{~h} ; \mathrm{P}<0.01,168 \mathrm{~h} ; \mathrm{P}<$ $0.05)$. However, there were not any changes in $\mathrm{L}(+)$ - and $\mathrm{D}(-)$-lactate levels after the change of diet. The ET level gradually increased from $6 \mathrm{~h}$ and, after reaching a maximum value of $167.7 \mathrm{ng} / \mathrm{ml}(\mathrm{P}<0.01)$ at $24 \mathrm{~h}$, it declined to the initial value at $168 \mathrm{~h}$ (Table 1). In VFA molar percentages, significant decreases in acetate and iso-valerianate and increase in propionate

Table 1. Changes of ruminal characteristics in goats engorged a high-concentrate ration $(\mathfrak{n}=3, \mathrm{Mean} \pm$ SD)

\begin{tabular}{|c|c|c|c|c|c|}
\hline Hour ${ }^{13}$ & $\mathrm{pH}$ & $\begin{array}{c}\mathrm{VFA} \\
\mathrm{mM} / \mathrm{d} l\end{array}$ & $\begin{array}{c}\mathrm{L}(+)-\text { lactate } \\
\mathrm{mg} / \mathrm{dl}\end{array}$ & $\begin{array}{c}\mathrm{D}(-)-\text { lactate } \\
\mathrm{mg} / \mathrm{d} l\end{array}$ & $\begin{array}{c}\text { Endotoxin } \\
\text { ng/dl }\end{array}$ \\
\hline-24 & $7.38 \pm 0.07$ & $6.42 \pm 0.41$ & $84.5 \pm 40.8$ & $134.6 \pm 62.4$ & $39.7 \pm 20.5$ \\
\hline 0 & $7.25 \pm 0.06$ & $7.52 \pm 0.72$ & $85.5 \pm 28.6$ & $134.8 \pm 42.4$ & $19.2 \pm 9.8$ \\
\hline 6 & $6.27 \pm 0.06^{* *}$ & $17.50 \pm 1.38^{* *}$ & $83.7 \pm 18.9$ & $135.0 \pm 31.5$ & $62.8 \pm 15.6$ \\
\hline 12 & $5.75 \pm 0.13^{* *}$ & $22.52 \pm 3.26^{* *}$ & $77.7 \pm 11.0$ & $125.9 \pm 17.1$ & $69.5 \pm 6.0$ \\
\hline 24 & $5.92 \pm 0.50^{* *}$ & $18.48 \pm 3.39^{* *}$ & $62.9 \pm 11.7$ & $102.4 \pm 18.5$ & $167.7 \pm 34.0^{* *}$ \\
\hline 48 & $6.81 \pm 0.15^{* *}$ & $9.66 \pm 1.12^{* *}$ & $66.6 \pm 21.5$ & $108.8 \pm 31.6$ & $120.3 \pm 66.4$ \\
\hline 72 & $6.54 \pm 0.49^{*}$ & $11.27 \pm 4.12$ & $56.4 \pm 25.6$ & $92.7 \pm 40.5$ & $112.7 \pm 97.3$ \\
\hline 168 & $6.51 \pm 0.51^{*}$ & $15.92 \pm 5.77^{*}$ & $84.8 \pm 40.6$ & $134.0 \pm 64.5$ & $42.6 \pm 18.7$ \\
\hline
\end{tabular}

1) Time after change of diet.

*.**; Values having asterisks are significantly different from the initial values $(0$ hour $)$ at $p<0.05$ or 0.01 , respectively. 


\section{Ruminal Endotoxin and Bacteria in Goats}

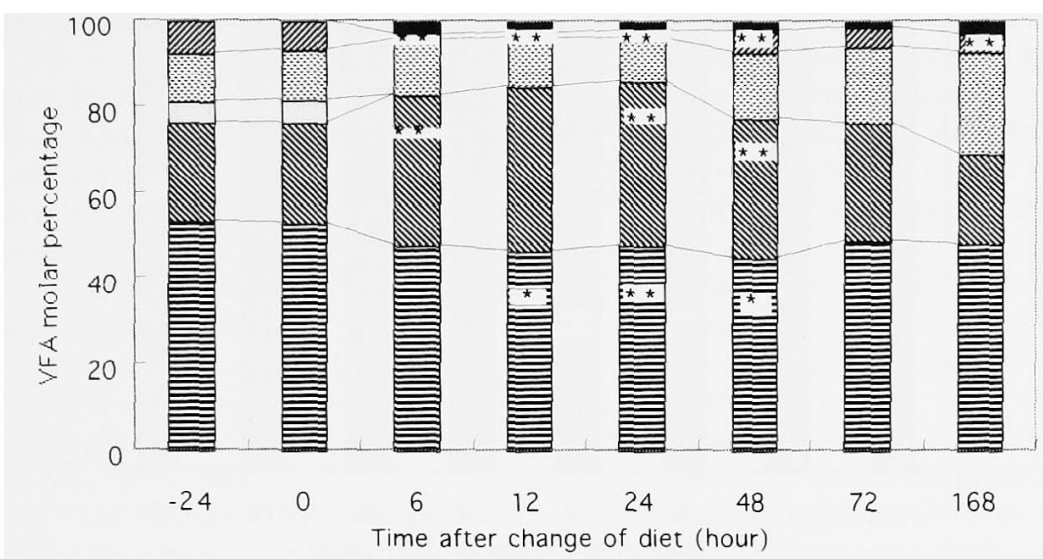

Fig. 1. Changes of VFA composition in ruminal fluids of goats engorged a high-concentrate ration $\left({ }^{*},{ }^{* *} ; \mathrm{P}<0.05,0.01\right.$ vs 0 h).

豆acetate propionate $\square$ iso-butyrate $\underset{*}{*}$ butyrate $\mathbb{Z}$ iso-valerianate

valerianate

Table 2. Changes of total numbers of bacteria and protozoa in ruminal fluids of goats engorged a highconcentrate ration $(n=3$, Mean $\pm S D)$

\begin{tabular}{|c|c|c|c|c|c|}
\hline \multirow{2}{*}{ Hour ${ }^{1)}$} & \multicolumn{3}{|c|}{ Bacteria, $\log / \mathrm{m} l$} & \multicolumn{2}{|c|}{ Protozoa } \\
\hline & Total & $G(-)-$ & $G(+)-$ & Total, $\log / \mathrm{m} l$ & Entodinium, \% \\
\hline-24 & $10.37 \pm 0.13$ & $10.31 \pm 0.11$ & $9.42 \pm 0.27$ & $5.54 \pm 0.04$ & $95.3 \pm 1.02$ \\
\hline 0 & $10.32 \pm 0.13$ & $10.26 \pm 0.11$ & $9.36 \pm 0.24$ & $5.61 \pm 0.04$ & $95.1 \pm 2.27$ \\
\hline 6 & $10.43 \pm 0.07$ & $10.38 \pm 0.06$ & $9.29 \pm 0.28$ & $5.28 \pm 0.08^{* *}$ & 93. $2 \pm 1.20$ \\
\hline 12 & $10.43 \pm 0.03$ & $10.36 \pm 0.07$ & $9.47 \pm 0.35$ & $4.88 \pm 0.06^{* *}$ & $91.3 \pm 3.50$ \\
\hline 24 & $10.59 \pm 0.14$ & $10.49 \pm 0.11$ & $9.75 \pm 0.38$ & 4. $88 \pm 0.18^{* *}$ & $84.7 \pm 8.90$ \\
\hline 48 & $10.37 \pm 0.16$ & $10.26 \pm 0.19$ & $9.64 \pm 0.17$ & $5.61 \pm 0.39$ & $89.4 \pm 6.67$ \\
\hline 72 & $10.34 \pm 0.10$ & 10. $26 \pm 0.09$ & $9.56 \pm 0.16$ & $5.90 \pm 0.06^{* *}$ & $91.5 \pm 3.09$ \\
\hline 168 & $10.44 \pm 0.20$ & $10.31 \pm 0.20$ & $9.80 \pm 0.25$ & $6.10 \pm 0.58$ & $87.2 \pm 9.90$ \\
\hline
\end{tabular}

1) Time after change of diet.

** ; Values having asterisks are significantly different from the initial values (0 hour) at $p<0.01$.

in comparison with $0 \mathrm{~h}$ were observed from 6 to $48 \mathrm{~h}(\mathrm{p}<0.05-0.01$; Fig. 1$)$.

The big changes in both numbers of grampositive and -negative bacteria were not observed, but they slightly increased at $24 \mathrm{~h}$. In protozoa, Entodinium was predominant and the total number significantly decreased at 6-24 and $72 \mathrm{~h}$ ( $\mathrm{P}<0.01$; Table 2$)$. In bacterial proportions, an increasing tendency in both gram -positive cocci at $6-168 \mathrm{~h}$ and gram-negative small rods at $6-12 \mathrm{~h}$ was obtained. Although the proportion of gram-negative cocci significantly decreased at $6-12 \mathrm{~h}(\mathrm{P}<0.05)$, it recovered to the initial level at $72 \mathrm{~h}$ (Fig. 2).

\section{Discussion}

An increase in ruminal ET level was observed in steers ${ }^{9)}$ and goats ${ }^{10)}$ induced acidosis by ruminal sucrose administration. The ET increase is usually accompanied with ruminal $\mathrm{pH}$ depression and lactate accumulation. In this study, however, the $\mathrm{pH}$ depression 


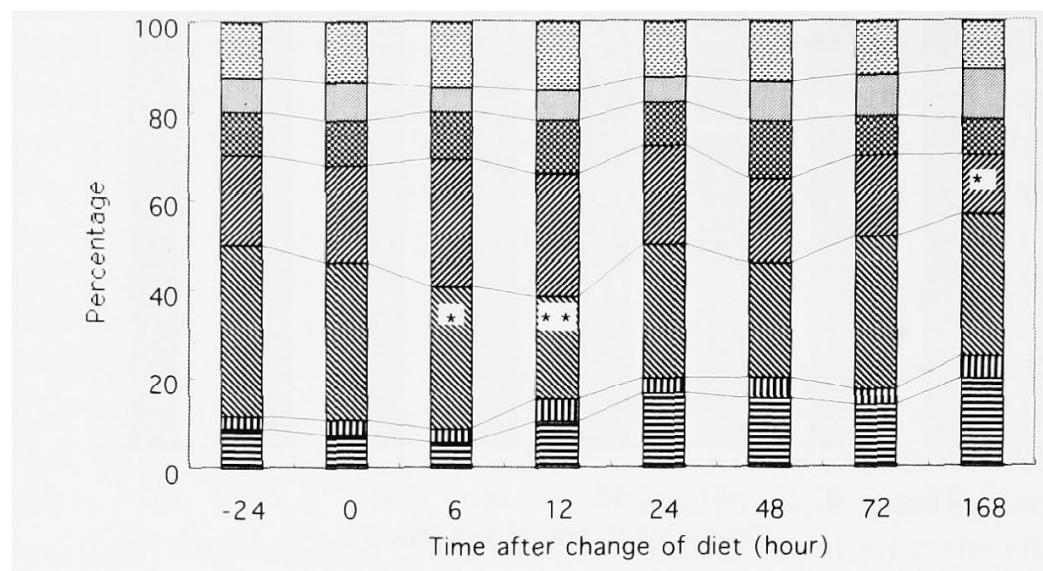

Fig. 2. Changes of bacterial proportion in ruminal fluids of goats engorged a high-concentrate ration $\left({ }^{*},{ }^{* *} ; \mathrm{P}<0.05,0.01\right.$ vs $\left.0 \mathrm{~h}\right)$.

$\equiv G(+)$ cocci III $G(+)$ rods $\mathbb{N} G(-)$ cocci $\mathbb{V}_{\mathbb{A}} G(-)$ small rods

G(-) large rods $\square G(-)$ curved rods $\mathrm{G}( \pm)$ cocci

followed by ET increase was caused by the elevation in VFA level, but not in lactate. Therefore, the ruminal fermentation after the change of diet is considered to be activated. Andersen et al. ${ }^{13}$ also observed similar changes in ruminal ET and $\mathrm{pH}$ of cattle fed on concentrate diets. These results suggest that ruminal ET production is stimulated not only in acidosis but also in normal feeding.

According to several researches ${ }^{1,4,5,9,10)}$, ruminal ET level seems to be widely varied from 112 to $4,497 \mathrm{ng} / \mathrm{m} l$ depending on animal species or rations. The ET level is generally thought to be caused by the decrease in the number of gram-negative bacteria in rumen. But, in this study, the number of gram-negative bacteria did not decrease in spite of increasing ruminal ET. Nagaraja et al. ${ }^{\text {) }}$ also reported the same results with this study in vitro culture of ruminal fluids and suggested that the decrease was dependent on bacterial multiplication and not on bacterial lysis. We conclude that the shift among the species of gram-negative bacteria was enhanced and the death in certain species of gram-negative bacteria would be reflected in ruminal ET production.
ET absorbed from rumen in acidosis animals has a lot of physiological activity and relates to several diseases through various cytokines ${ }^{5}$. Suda et $a .^{9)}$ reported the death in steers induced acidosis after the extreme elevations of both ruminal and serum ET which were more than 10 -fold. In the present study, the ruminal ET increase was less 10-fold and severe clinical signs were not observed. Therefore, if ruminal ET level could be maintained at a certain range, even if a large amount of ET is produced in rumen, the ET related diseases would not occur.

In conclusion, it was clarified that ET production increased without a decrease in the number of gram-negative bacteria, when ruminal fermentation was activated.

\section{References}

1) Anderson $\mathrm{PH}$, Bergelin $\mathrm{B}$, Christensen $\mathrm{KA}$. Effect of feeding regimen on concentration of free endotoxin in ruminal fluid of cattle. J. Anim. Sci., 72 : 487-491. 1994.

2) Dougherty RW, Cello RM. Study of toxic factors in the rumen ingesta of cows and sheep. Cornell Vet., 39 : 403-413. 1949.

3) Huber TL, Peed MC, Wilson RC, Goetsch DD. Endotoxin absorption in hay-fed and lactic 
acidotic sheep. Am. J. Vet. Res,, 10:792-794. 1979.

4) Mochizuki M, Kamata N, Itoh T, Shimizu G, Yamada Y, Kadosawa T, Nishimura R, Sasaki $\mathrm{N}$, Takeuchi A. Postparturient change in endotoxin levels of ruminal fluid and serum in dairy cows. J. Vet. Med. Sci., 58:577-580. 1996.

5) Motoi $Y$, Oohashi $T$, Hirose $H$, Hiramatsu $M$, Miyazaki S, Nagasawa S, Takahashi J. Turbidimetric-kinetic assay of endotoxin in rumen fluid or serum of cattle fed rations containing various levels of rolled barley. J. Vet. Med. Sci., 55: 19-25. 1993.

6) Mullenax $\mathrm{CH}$, Keeler RF, Allison $\mathrm{MJ}$. Physiologic responses of ruminants to toxic factors extracted from rumen bacteria and rumen fluid. Am. J. Vet. Res., 27 : 857-868. 1966.
7) Nagaraja TG, Bartley EE, Fina $L R$, Anthony HD. Relationship of rumen gram-negative bacteria and free endotoxin to lactic acidosis in cattle. J. Anirm. Sci., 47 : 1329-1337. 1978.

8) Ogimoto K, Imai S, Rumen Protozoa. In : Atlas of Rumen Microbiology (Ogimoto K, Imai S eds.). 9-67. Japan Scientific Press. Tokyo. 1981.

9) Suda K, Hiramatsu M, Motoi Y. Changes of ruminal fora and endotoxin concentration in acidosis steers induced by sucrose injection. Anim. Sci. Technol. (Jpn.), 65 : 1143-1149. 1994.

10) Suda $K$, Kobayashi $Y$, Hiramatsu $M$, Arai $S$, Motoi Y, Wakita M, Hoshino S. Changes of ruminal characteristics in acidotic goats induced by sucrose injection. Anim. Sci. Technol. (Jpn.), 67 : 353-359. 1996.

\title{
濃厚飼料を飽食させたやギのルーメン内エンドトキシン濃度 之細菌数との関係
}

\author{
須田久也・吉岡 都 ${ }^{1)} \cdot$ 元井臀子1) - 小林泰男 ${ }^{22}$

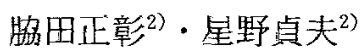 \\ 科研製薬，東京都中央区 103 \\ 1) 農林水産省家畜衛生試験場, つくば市 305 \\ 2) 三重大学生物資源学部，津市 514
}

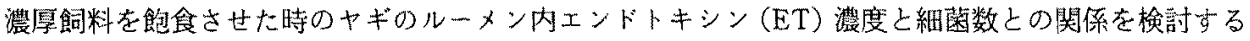
ことを目的とした．粗飼料で飼育したルーメンフィステル装着ヤギ 3 頭を供試し，実験当日から $90 \%$ 濃 厚飼料多給に切り換えて不断給与した。いず机のやギ飼料切換後すぐに食欲不振や元気消失などのア シトーシス様の臨床症状を示した、ルーメン内ではVFA 激度の有意な上昇を伴った $\mathrm{pH}$ の有意な低下 がみられ，VFAのモル比では，6-48 時間後にプロビオン酸の増加やイソ吉草酸の低下がみられた，L

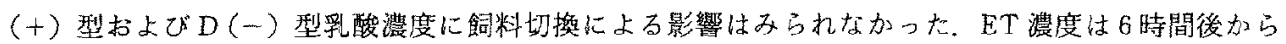
徐々に上昇し， 24 時問後に最大值の $167.7 \mathrm{ng} / \mathrm{m} l$ に達した後，168 時間後には初期值に回復した。グラ ム陽性，陰性菌数とも24 時間淩にわずかに增加する傾向がみられた。 その割合では，6-12 時間後にグラ 么陽性球菌が増加㑯向を示し，グラム陰性球蘶が有意に減少した。プロトゾア数は6-24およよび 72 時間 後に有意に隇少した，以上より，濃厚飼料飽食に切り換えたヤギでは，ルーメン内グラム陰性菌数が隇 少することなく，ET 髥度が高まることが判明した，
\end{abstract}

